\title{
T A N M A L A K A \\ (Ditinjau dari presfektif perjuangan bangsa)
}

\author{
Randy Fadillah Gustaman* \\ Tenaga Pendidik FKIP-Universitas Siliwangi \\ Jl. Siliwangi No. 24 Kahuripan, Tawang, Tasikmalaya, Jawa Barat 46115
}

\begin{abstract}
ABSTRAK
Jenis penelitian dalam penulisan ini menggunakan penelitian deskriptif. Tujuan dari penelitian ini adalah untuk mengetahui sepak terjang Bapak Republik Indonesia yaitu Tan Malaka dalam perjuangan kemerdekaan Bangsa Indonesia. Teknik pengumpulan data dalam penelitian ini adalah dengan menggunakan riset kepustakaan (library research). Studi pustaka adalah metode pengumpulan data yang diarahkan kepada pencarian data melalui dokumen, baik tertulis, maupun dokumen elektronik yang dapat mendukung dalam proses penelitian.

Kemerdekan Negara Republik Indonesia banyak sekali melahirkan tokoh-tokoh perjuangan bangsa yang sangat berjasa bagi tegaknnya Negara Republik Indonesia, salah satunya adalah Tan Malaka. Ia merupakan seorang tokoh yang sedikit asing di telinga kita apabila membicarakan tentang sejarah perjuangan bangsa. Akan tetapi tidak bisa kita pungkiri bahwa beliau merupakan salah satu orang yang berjuang dengan jalan pikirannya sendiri untuk memerdekakan Negara Indonesia. Bagaimana tidak, sebelum para founding father mengemukakan konsep-konsep dan gagasan-gagasan mereka terhadap Negara Indonesia, Tan Malaka pada tahun 1924 mengemukakan konsepsi mengenai kemerdekaan Negara Indonesia dalam sebuah buku yang diberi judul Naar De Republiek Indonesia (menuju republiek Indonesia). Pemikiran dan Gagasannya banyak dijadikan sumber referensi oleh tokoh-tokoh nasional lainnya. Presiden pertama Republik Indonesia yang menjadikan beberapa karya Tan Malaka sebagai referensi dasar, seperti konsep massa actie dikutip oleh Soekarno dalam pleidoinya, Indonesia Menggugat.
\end{abstract}

\section{Kata Kunci: Tan Malaka, Perjuangan Bangsa}

\begin{abstract}
This research used a descriptive method. The aim of the research is to know the struggle of the Father of Indonesian i.e. Tan Malaka in liberating Indonesian from the colonialists. Library research is used as the technique to collect the data of the research. Book study is the method of collecting data means to finding the data through documents whether the written or the electronic documents which aid the research process.

Liberation of Indonesia Republic State has appeared many founding father figures of Indonesia who have given a lot of benefit of the existence of Indonesia Republic State and one of them is Tan Malaka. He looks like an odd figure when people speak about the history of Indonesia liberation. But, it could not be refused that he has fought to make Indonesia free by his way. He has stated a lot of consepts and ideas as the way to liberate Indonesia before the other founding fathers did it. In 1924, Tan Malaka stated the conception of how to make Indonesia free from the colonialists in a book entitled "Naar De Republiek Indonesia" or Into Indonesia Republic. His Ideas has become the reference resources by the other nationalist figures. Including the first president of Indonesia, Mr. Soekarno, who used the masterpiece of Tan Malaka as the basic reference, such as massa actie concept is copied by Soekarno in his pledoi i.e. Indonesia Menggugat.
\end{abstract}

\section{Keywords: Tan Malaka, Struggle of the Nation}

\footnotetext{
* Penulis Koresponden

E-mail address: bluemei.d51@gmail.com doi:
} 


\section{PENDAHULUAN}

Dewasa ini Indonesia menglami krisis multidimensional yang menghambat perkembangan Negara ini. Krisis multidimensi tersebut seharusnya bisa diatasi dengan kesadaran generasi muda terhadap perannya baik dalam kehidupan berbangsa ataupun bernegara, kesadaran tersebut tidak akan tumbuh dan bersemayam di dalam individu generasi peneus bangsa apabila generasi muda tersebut tidak memahami arti penting sebuah kemerdekaan, memahami kemerdekaan tidk akan lepas dari memahami sejarah bangsanya, sejarah pada dasarnya merupakan sebuah kajian yang selalu berkembang setiap waktu, dengan adanya bukti serta penemuan yang terbarukan dapat menambah wawasan dan pengetahuan dan terjaminannya obyektifitas penulisan sejarah, khususnya sejarah nasional, baik sejarah sebelum kemerdekaan ataupun pasca kemerdekaan Negara Indonesia. Banyak cara untuk bisa mempelajari sejarah bangsa indonesia, salah satunya dengan lebih mengenal dan memahami tokoh-tokoh yang berperan aktif dalam memerdekakan Negara Republik Indonesia sampai titik darah penghabisan.

Kemerdekan Negara Republik Indonesia banyak sekali melahirkan tokoh-tokoh perjuangan bangsa yang sangat berjasa bagi tegaknnya Negara Republik Indonesia, salah satunya adalah Tan Malaka. Ia merupakan seorang tokoh yang sedikit asing di telinga kita apabila membicarakan tentang sejarah perjuangan bangsa. Akan tetapi tidak bisa kita pungkiri bahwa ia merupakan salah satu orang yang berjuang dengan jalan pikirannya sendiri untuk memerdekakan Negara Indonesia. Bagaimana tidak, sejarah mencatat, jauh sebelum para founding father mengemukakan konsep-konsep mereka terhadap Negara Indonesia, Tan Malaka pada tahun 1924 mengemukakan konsepsi mengenai kemerdekaan Negara Indonesia dalam sebuah buku yang diberi judul Naar De Republiek Indonesia (menuju republik Indonesia).

Sosok Tan Malaka merupakan sosok yang sedikit tertutup, dan penuh dengan tanda Tanya, bayangkan saja seorang Tan Malaka memiliki 23 nama palsu dan telah menjelajahi dua benua dengan total perjalanan sepanjang 89 ribu kilometer (Tim Edisi Khusus Tan Malaka, 2010: 2). Setiap Tan Malaka hijrah ke tempat yang berbeda hampir semuanya berganti nama dengan kata lain menggunakan nama samara dalam kesehariannya, hal itu disebabkan Tan Malaka memiliki rasa traumatik yang begitu mendalam terhadap penjajah belanda dan sekutunya yang selalu mencari dan ingin menanggkapnya, hal itu dikarenakan Tan Malaka di anggap berbahaya oleh pemerintah Kolonial. Ia merupakan salah satu pejuang kemerdekaan Republik Indonesia, yang memilih menggunakan revolusi sebagai alat perjuangannya. Sebagai tokoh pejuang dia memberikan contoh kepada bangsa ini bagaimana berjuang dengan sangat militan, radikal (akan tetapi dengan penuh pertimbangan) dengan jiwa revolusioner yang sangat kuat, ia percaya bahwa kemerdekaan bisa di rebut dengan cara melawan penjajah tanpa sebuah perundingan. Menurut Poeze (2010) Tan Malaka berkukuh, sebagai pemimpin revolusi Soekarno semestinya mengedepankan perlawanan gerilya ketimbang menyerah. Baginya, perundingan hanya bisa dilakukan setelah ada pengakuan kemerdekaan Indonesia 100 persen dari Belanda dan Sekutu, Tanpa itu, nonsense (Tim Edisi Khusus Tan Malaka, 2010: 3). Berdasarkan analisis pemikiran Tan Malaka, revolusi melahirkan sebuah tatanan masyarakat baru yang beradab dan negara menghargai nilai kemanusiaan dan hak politik warga negara. Bukan diktator proletar yang menindas rakyat (Syam dan faisal, 2015: 1579)

\section{METODE PENELITIAN}

Jenis penelitian ini merupakan penelitian deskriptif. Tujuan penelitian deskriptif yaitu untuk membuat deskripsi, gambaran, lukisan secara sistematis, faktual dan akurat mengenai fakta-fakta mengenai fenomena yang diselidiki. Dengan demikian, laporan penelitian akan berisi kutipan-kutipan data untuk memberi gambaran penyajian laporan tersebut (Moleong, 2005). Teknik pengumpulan data dalam penelitian ini adalah dengan menggunakan riset kepustakaan (library research). Studi pustaka adalah metode pengumpulan data yang diarahkan kepada pencarian data melalui dokumen, baik dokumen tertulis, maupun dokumen elektronik yang dapat mendukung dalam proses penulisan."Hasil penelitian juga akan semakin kredibel apabila didukung foto-foto atau karya tulis akademik dan seni yang telah ada."(Sugiyono,2005:83). 


\section{PEMBAHASAN}

\section{Riwayat Tan Malaka}

Tan Malaka atau Ibrahim gelar Datuk Tan Malaka lahir di Nagari Pandan Gadang, tak jauh dari Suliki, di Minangkabau, Sumatera Barat, lahir sekitar tahun 1894, dari orang tuanya tergolog bangsawan lokal (Poeze, 2008: XV). ketika beliau lahir sedang terjadi penjajahan fisik di Indonesia sehingga tidak semua bumi putra atau masyarakat pribumi asli dapat mengenyam pendidikan formal dengan baik, pada saat itu pendidikan dijadikan sebagai suatu bentuk yang bersifat pemberian kaum penjajah dan hanya diberikan kepada kalangan borjuis. Tan Malaka merupakan salah satu tokoh yang termasuk beruntung karena dapat menikmati pendidikan sekolah pada masanya.

Tan Malaka memulai pendidikan di sekolah rendah, dan begitu pandai sehingga guru-gurunya mempersiapkannya untuk mengikuti ujian masuk sekolah Guru Pribumi (Inlandsche Kweekschool voor Onderwijzers) di Bukittinggi, yang merupakan satu-satunya lembaga untuk pendidikan lanjutan di Sumatra, Tan Malaka lulus dan meneruskan di Sekolah Guru dengan sukses pada tahun 1908-1913 (Poeze, 2008: XV). Setelah menyelesaikan penidikan di sekolah Guru Pribumi (Inlandsche Kweekschool voor Onderwijzers) kemudian di akhir tahun 1913 sampai pertengahan 1915 tinggal di Haarlem atas jasa salah satu gurunya. G.H Horensma seorang guru dari belanda yang ingin mengusahakan Tan Malaka agar dapat melanjukan sekolahnya di Belanda. Ia berhasil mendapatkan tempat untuk Tan Malaka di Kweekschool Haarlem (Belanda) dan juga mengurus dana untuk perjalanan dan belajarnya, selain juga ikut menyumbangkan dana khusus dari Suliki (Poeze, 2008: xv). Setelah selesai menyelesaikan pendidikan di belanda, sosok Tan Malaka selalu berpindah-pindah tempat, mulai dari Banten (Indonesia), Moskow (Uni Soviet), China, Filipina, Thailand, Malaka, Burma dan tempat lainnya sampai ia meninggal pada tanggal 21 Februari 1949 di Jawa Timur. Tan malaka banyak menghabiskan waktu hidupnya di luar negeri dikarenakan Tan Malaka selalu berada dalam bayang-bayang penangkapan yang dipelopori oleh belanda dan sekutunya.

\section{Tan Malaka dalam Perjuangan Bangsa Indonesia}

Sebagai seorang pahlawan Sosok Tan Malaka memang tidak terlalu dikenal seperti pahlawan lainnya, akan tetapi berdasarkan fakta sejarah seorang Tan Malaka di kancah perjuangan kemerdekaan Indonesia merupakan tokoh pertama yang menggagas secara tertulis konsep Republik Indonesia. Ia menulis Naar de Republiek Indonesia (Menuju Republik Indonesia) pada tahun 1924, jauh lebih dulu dibanding Mohammad Hatta, yang menulis Indonesia Vrije (Indonesia Merdeka) sebagai pleidoi di depan pengadilan Belanda di Den Haag tahun 1928, dan Bung Karno, yang menulis Menuju Indonesia Merdeka tahun 1933 (Tim Edisi Khusus Tan Malaka, 2010: 1).

Tan Malaka merupakan tokoh perjuangan yang sangat disegani baik lawan ataupun kawan. Pemikiran dan tindakannya banyak dijadikan referensi oleh tokoh-tokoh yang lain. Dikutip dari buku Bapak Republik Yang Dilupakan (2010:2) beberapa tokoh yang menjadikan gagasan tan malaka sebagai referensi diantaranya adalah presiden pertama Republik Indonesia yang menjadikan beberapa karya Tan Malaka sebagai sumber pemikiran, bahkan gagasan Tan Malaka yang tertulis di dalam karya yang berjudul massa actie dikutip Bung Karno dalam pleidoinya, Indonesia Menggugat, tidak ketinggalan W.R. Supratman pun telah membaca habis Massa Actie. Ia memasukkan kalimat "Indonesia tanah tumpah darahku" ke dalam lagu Indonesia Raya setelah diilhami bagian akhir dari Massa Actie, pada bab bertajuk "Khayal Seorang Revolusioner ". Di situ Tan Malaka antara lain menulis, "Di muka barisan laskar, itulah tempatmu berdiri, kewajiban seorang yang tahu kewajiban putra tumpah darahnya."

Latar Belakang pendidikan Tan Malaka sangat berpengaruh terhadap kepeduliannya terhadap mental dan intelektualitas bangsanya. Pentingnya menumbuhkan tingkat intelektualitas bangsa indonesia di samping perjuangan secara fisik menjadi alasan kuat baginya untuk menuangkan gagasan-gagasan revolusioner dalam bentuk karya tulis. Tan Malaka menuangkan berbagai gagasannya ke dalam buku, brosur dan ratusan artikel di berbagai surat kabar terbitan Hindia Belanda. Menurut Asral, DP (2007) sebagaimana dikutip oleh Hambali (2015: 200) Karya-karya Tan Malaka yang teridentifikasi adalah Di antaranya,

1) Parlemen atau Soviet (1920),

2) SI Semarang dan Onderwys (1921),

3) Dasar Pendidikan(1921),

4) Naar de Republiek Indonesia(1924),

5) Semagat Muda(1925),

6) Massa Actie (1926), 
7) Manifesto Bangkok (1927),

8) Pail dan hitenviional (1927),

9) Pan dan PKI (1927),

10) Pail dan Nasionalisten (1927),

11) Asia Bergabung (1943),

12) Madilog(1943),

13) Manifesto Jakarta (1945),

14) Politik (1945),

15) Rencana Ekonomi Berjuang (1945),

16) Muslihat(1945),

17) Thesis (1946),

18) Pidato Purwokerto (1946),

19) Pidato Solo (1946),

20) Islam dalam Tinjauan Madilog (1948),

21) Pandangan Hidup (1948),

22) Kuhandel di Kaliurang (1948),

23) PidatoKediri (1948),

24) Gerpolek (1948),

25) Isi dan Pelaksanaannya (1948), dan

26) Dari Penjara ke Penjara (3 jilid,1948). (Hambali 2015: 100)

Di seputar Proklamasi, pada awal bulan juni tahun 1945 Tan Malaka datang ke Jakarta dengan misi untuk menghadiri kongres para pemuda dan menyamarkan dirinya dengan nama Iljas Hussain dan mengaku berasal dari banten. Hal ini terbukti sebagaimana di tulis oleh tan malaka sendiri dalam gagasan MADILOG ia menyatakan "Demikianlah pengarang ini yang pada masa Jepang itu memperkenalkan dirinya dengan nama Iljas Hussain (Tan Malaka, 1943: 1-2). Tan malaka yang identik dengan penyamarannya itu berusaha agar identitasnya tidak ada yang mengetahui dikarnakan rasa takut yang berlebihan terhadap ancaman terhadapnya (ancaman penangkapan dari pemerintah colonial belanda dan para sekutunya).

Kongres para pemuda di Jakarta di jadikan oleh Iljas Hussain (Tan Malaka) sebagai moment yang luar biasa Karena dalam kongres tersebut dia dapat bertemu, berkumpul dan bertukar pemikiran, gagasan dan masukan dengan tokoh perjuangan kemerdekaan Indonesia, khususnya dari kalangan muda seperti sukarni, Chairul saleh dll.

Disinilah saya berjumpa dengan pemuda seperti Sukarni, Chairul Saleh, dll. yang sekarang mengambil bagian dalam pergerakan Persatuan Perjuangan. Juga dengan pemuda lainnya umpamanya seorang jurnalis yang amat dikenal di sekitar Bayah ketika itu, tak lebih dan tak kurang dari Bang Bejat, alias Anwar Tjokroaminoto dan saudaranya. Resan minyak ke minyak, resan air ke air, kata pepatah (Tan Malaka, 1943:1)

Iljas Hussein menyampaikan konsep analisisnya tentang perjuangan kemerdekaan Indonesia waktu itu. Konsep dan analisis seorang Iljas Hussein tentang perjuangan kemerdekaan (Proklamasi) membuat Sukarni kagum dan sedikit banyak mempengaruhi cara pandang sukarni terhadap perjuangan kemerdekaan bangsa Indonesia.

Selanjutnya, Sosok Tan Malaka kembali Mucul pada Tanggal 6 Agustus 1945 di kediaman B.M Dyah. dia masih memperkenalkan diri dengan nama Ilyas Hussain dari Bayah dan mengaku sebagai utusan dari para pemuda yang ada di daerah bayah. Utusan Bayah itu menanyakan kabar mutakhir situasi perang. Setelah satu jam B.M Dyah memberikan informasi, Iljas Hussain menyatakan pendapatnya. "pimpinan revolusi kemerdekaan harus di tangan pemuda" (Tim Edisi Khusus Tan Malaka, 2010: 9)

Pada tanggal 25 Agustus Tan Malaka mendatangi kediaman Achmad Soebardjo (Menteri Luar Negeri), salah seorang teman lama yang pernah bertemu dengannya ketika menuntut ilmu di negei belanda.dikutip dari buku Tan Malaka, Bapak Republik Yang dilupakan (2010: 11) Sejak itu Tan diperkenalkan kepada beberapa tokoh seperti Iwa Koesoema Soemantri, Gatot Taroenamihardjo, Boentaran Martoatmojo. Ia juga dipertemukan dengan Nishijima Shigetada, Asisten Laksamana Maeda. Di depan Nishijima, ia bicara tentang revolusi, struktur politik, gerakan massa, hingga propaganda. Sampai pada akhirnya berita mengenai kemunculan tan malaka sampai kepada presiden soekarno dan mengutus Sayuti melik untuk menemuinya. Setelah bertemu dengan tan malaka, soekarno membuat testimony politik yang intinya Bila Soekarno-Hatta tidak berdaya lagi, pimpinan perjuangan akan diteruskan oleh Tan Malaka, Iwa Koesoema, Sjahrir, dan Wongsonegoro (Tim Edisi Khusus Tan Malaka, 2010: 12). Dari testimony tersebut bisa disimpulkan bahwa Soekarno sangat mengagumi dan memahami alur pemikiran sosok tan malaka sehingga dia mempercayakan kepada serorang tan malaka untuk memimpin perjuangan apabila terjadi sesuatu hal yang tidak di inginkan terjadi padanya ataupun juga pada $M$. Hatta yang saat itu menjadi presiden dan wakil presiden Negara Indonesia. 
Walaupun secara hakikat Tan Malaka memiliki peranan penting, sangat disayangkan ketika dalam pelaksanaan proklamasi kemerdekaan indonesia tanmalaka terkesan tidak memiliki kontribusi besar hal ini senada dengan apa yang di katakana oleh Adam Malik, Dalam buku Riwayat Proklamasi Agustus 1945, Adam Malik melukiskan peristiwa itu sebagai "kepedihan riwayat". Sukarni bertahun-tahun membaca buku politik Tan. Tapi pada saat ia membutuhkan pikiran dari orang sekaliber Tan, Sukarni sungkan bertanya siapa Hussein sesungguhnya. "Ia malah membiarkannya pergi jalan kaki, lepas dari pandangan mata," kata Adam Malik (Tim Edisi Khusus Tan Malaka, 2010: 9). Sejarah mencatat bahwa Tan Malaka memiliki peran yang terbatas di dalam proklamasi kemerdekaan. Terbatasnya peran Tan Malakaitu, kata Poeze, sungguh ironis. Padahal Tan orang Indonesia pertama yang menggagas konsep republik dalam buku Naar de Republiek Indonesia, yang ditulis pada 1924. Buku kecil ini kemudian menjadi pegangan politik tokoh pergerakan, termasuk Soekarno (Tim Edisi Khusus Tan Malaka, 2010: 11) akhirnya disadari oleh Tan Malaka bahwa ia tidak ditakdirkan ambil bagian dalam proklamasi kemerdekaan Indonesia.

Setelah Indonesia mengumandangkan proklamasi kemerdekaan Tan Malaka terus berperan aktif dalam perjuangan, karena dia menyadari bahwa perjuangan bangsa Indonesia belum selesai. Setelah proklamasi Tan Malaka melanjutkan perannya yang tidak kalah penting. Ia menggerakkan para pemuda ke rapat raksasa di Lapangan Ikada (kini kawasan Monas), 19 September 1945. Inilah rapat yang menunjukkan dukungan massa pertama terhadap proklamasi kemerdekaan yang waktu itu belum bergema keras dan "masih sebatas catatan di atas kertas". Tan Malaka menulis aksi itu "uji kekuatan untuk memisahkan kawan dan lawan". Setelah rapat ini, perlawanan terhadap Jepang kian berani dan gencar ( Tim Edisi Khusus Tan Malaka, 2010: 2)

Tidak cukup sampai situ perjuangan Tan Malaka yang sudah tidak sejalan lagi secara pemikiran dan program terhadap PKI memilih memisahkan atau keluar dari partai komunis tersebut dan membentuk partai MURBA (Musyawarah Rakyat Banyak). Hal tersebut menunjukan bahwa ia merupakan sosok seorang yang sangat keras dan teguh pendiriannya terhadap sebuah gagasan. Peran Tokoh Bapak RepubliK Indonesia yang bernama Tan Malaka tidak berhenti sampai pendirian partai murba, menurut Poeze (2008: XI), pada saat terjadi serangan belanda pada Desember 1948 Tan Malaka berada di Kediri , Jawa Timur dan bergabung dalam sebuah satuan pasukan grilya. Dapat di artikan bahwa Tan Malaka merupakan sosok yang militan dalam perjuangan, rasa cintanya terhadap Negara Indonesia yang begitu besar mampu mengalahkan berbagai kepentingan pribadi yang ada dalam dirinya.

\section{PENUTUP}

\section{Simpulan}

Sosok Tan Malaka yang merupakan Bapak Republik Indonesia merupakan orang yang dengan semangat dan tanpa pamrih berjuang dalam memerdekakan Negara Indonesia. Semangat nasionalismenya yang begitu tinggi mampu berada di atas kepentingan lain. Tan Malaka merupakan tokoh pertama yang memiliki gagasan yang dituangkan dalam bentuk tertulis mengenai konsep Negara Indonesia yang berjudul. Naar de Republiek Indonesia (Menuju Republik Indonesia) pada tahun 1924, baru setelah itu bermunculan gagasan-gagasan lain dari para tokoh lain seperti: Mohammad Hatta, yang menulis Indonesia Vrije (Indonesia Merdeka) sebagai pleidoi di depan pengadilan Belanda di Den Haag tahun 1928, dan Bung Karno, yang menulis Menuju Indonesia Merdeka tahun 1933 (Tim Edisi Khusus Tan Malaka, 2010: 1). Tan Malaka Juga tidak hanya sekedar menyuarakan pemikirannya tentang gagasan dan konsep politiknya saja, ketika belanda menyerang kembali ibu pertiwi, Tan Malaka tidak gentar, ia ikut bergabung dengan pasukan grilya yang berada di Kediri, Jawa Timur untuk mempertahankan kemerdekaan Negara Republik Indonesia seperti apa yang ia cita-citakan sejak dulu.

\section{DAFTAR PUSTAKA}

Faisal dan Firdaus Syam. 2015. Tan Malaka, Revolusi Indonesia. Terkini Jurnal Kajian Politik Dan Masalah Pembangunan VOL. 11 No. 01.2015

Hambali. 2015. Konsep Pendidikan Dalam Perspektif Tan Malaka (Tokoh Revolusioner Prakemerdekaan) Jurnal Intelektualita Volume 3, Nomor 1 JanuariJuni 2015) 
Malaka, Tan. 1943. Madilog. Ebook bersumber dari Terbitan Widjaya, Jakarta, tahun 1951

Malaka, Tan. 2000. Massa Aksi. Jakarta: Komunitas Bambu.

Poeze, Harry A. 2010. Tan Malaka Gerakan Kiri, dan Revolusi Indonesia (Jilid 1: Agustus 1945-Maret 1946), Jakarta: Yayasan Obor Indonesia

2010. Tan Malaka Gerakan Kiri, dan Revolusi Indonesia (Jilid 2: Maret 1946Maret 1947), Jakarta: Yayasan Obor Indonesia

-------. 2010 Tan Malaka Gerakan Kiri, dan Revolusi Indonesia (Jilid 3: Maret 1947Agustus 1948), Jakarta: Yayasan Obor Indonesia

Sugiyono. 2009. Metode Penelitian Kuantitatif dan Kualitatif. CV.Alfabeta: Bandung.

Tim Edisi Khusus Tan Malaka, 2010. Tan Malaka, Bapak Republik Yang Dilupakan (Seri Buku Tempo: Bapak Bangsa), Jakarta: KGP. 